Jurnal Bidan Cerdas
e-ISSN: 2654-9352 dan p-ISSN: 2715-9965
Volume 3 Nomor 1 2021
DOI: $10.33860 / j b c . v 3 i 1.358$
Website: http://jurnal.poltekkespalu.ac.id/JBC
Penerbit: Poltekk Kemenkes Palu

\title{
Gambaran Kejadian Risiko 4T pada Ibu Hamil di Puskesmas Jatinangor
}

\author{
Ajeng Maulani Hazairin', Auliya Nurul Arsy1, Rosalinda Agnestya Indra1, \\ Ari Indra Susanti ${ }^{\star}$ \\ ${ }^{1}$ Diploma IV Kebidanan Fakultas Kedokteran Universitas Padjadjaran \\ ${ }^{2}$ Departemen IImu Kesehatan Masyarakat, Fakultas Kedokteran, Universitas Padjadjaran \\ open \\ *Email korespondensi: ari.indra@unpad.ac.id
}

access

ARTICLE INFO

Article History:

Received: 2020-12-04

Accepted: $2020-12-30$

Published: 2020-02-28

Kata Kunci:

Risiko 4T;

Terlalu muda; terlalu

tua; Terlalu banyak;

Ibu Hamil;

\section{Keywords:}

high risk pregnancy; too young; too old; too many;

Pregnant;

\begin{abstract}
ABSTRAK
Pendahuluan: Kehamilan risiko tinggi ditemukan pada ibu hamil yang terlalu tua, terlalu muda, terlalu banyak dan terlalu dekat (4T). Terdapat banyak masalah/faktor risiko yang menjadi skrining/ deteksi dini ibu hamil di dalam kartu skor poedji rochjati diantaranya adalah usia ibu $<16$ tahun, usia ibu >35 tahun, dan ibu yang memiliki anak 4/lebih. Tujuan penelitian ini adalah untuk mengetahui gambaran kejadian risiko $4 \mathrm{~T}$ pada ibu hamil di Puskesmas Jatinangor tahun 2020. Metode: Jenis penelitian yang digunakan adalah deskriptif analitik dengan pendekatan kuantitatif dan desain cross-sectional. Populasi dalam penelitian ini adalah seluruh ibu hamil yang berada di Puskesmas Jatinangor periode bulan JanuariSeptember 2020 yaitu berjumlah 2357 orang, menggunakan teknik accidental sampling dan didapatkan jumlah sampel sebanyak 149 orang. Analisis data menggunakan analisis data deskriptif dengan distribusi frekuensi. Hasil: hasil penelitian menunjukkan bahwa responden yang memiliki risiko 4T paling banyak pada usia lebih dari 35 tahun sebesar $63,19 \%$, dan pada paritas multipara sebesar $43,62 \%$. Kesimpulan: Pada penelitian ini didapatkan bahwa kejadian risiko $4 \mathrm{~T}$ pada ibu hamil di Puskesmas Jatinangor tahun 2020 paling banyak terjadi pada risiko terlalu tua sebesar $58,3 \%$ yang didominasi oleh multiparitas.
\end{abstract}

\section{ABSTRACT}

Introduction: High-risk pregnancies are found in pregnant women who are too old, too young, too many, and too close (4T). Many risk factors become screening/early detection of pregnant women in the Poedji Rochjati scorecard, including maternal age $<16$ years, maternal age $>35$ years, and mothers who have children 4 or more. Objective: The aim of this study was to describe the $4 \mathrm{~T}$ risk incidence in pregnant women at the Jatinangor Community Health Center in 2020. Methods: The type of research used was descriptive-analytic with a quantitative approach and cross-sectional design. The population in this study were all pregnant women who were in Jatinangor Health Center. January-September 2020 period, amounting to 2357 people, using accidental sampling technique and obtained a total sample of 149 people. Data analysis using descriptive data analysis with frequency distribution. Results: The results showed that respondents who had the highest risk of $4 \mathrm{~T}$ were $63.19 \%$ at the age of more than 35 years, and multiparity of $43.62 \%$. Conclusion: In this study, it was found that the incidence of $4 \mathrm{~T}$ risk in pregnant women at the Jatinangor Health Center in 2020 was mostly at the risk of being too old by $58.3 \%$ which was dominated by multiparity. 


\section{PENDAHULUAN}

Kehamilan merupakan keadaan yang fisiologis terjadi pada wanita. Akan tetapi, dapat diikuti proses patologis yang mengancam keadaan ibu dan janin. United Nations International Children's Emergency Fund (UNICEF) tahun 2012, menyatakan bahwa setiap tahun hampir 10.000 wanita meninggal karena masalah kehamilan dan persalinan. Angka Kematian Ibu (AKI) merupakan salah satu indikator dalam menentukan derajat kesehatan masyarakat dan keberhasilan pembangunan pada sektor kesehatan. Tinggi rendahnya AKI di suatu wilayah dijadikan sebagai indikator yang menggambarkan besarnya masalah kesehatan, kualitas pelayanan kesehatan, dan sumber daya di suatu wilayah (Kurniasari et al., 2015).

Secara umum, terjadi penurunan kematian ibu selama periode 1991-2015 dari 390 menjadi 305 per 100.000 kelahiran hidup. Dengan adanya, kecenderungan penurunan angka kematian ibu, maka tidak dapat mencapai target MDGs sebesar 102 per 100.000 kelahiran hidup pada tahun 2015 (Kemenkes RI, 2019).

Hasil Survei Penduduk Antar Sensus (SUPAS) tahun 2015 memperlihatkan angka kematian ibu tiga kali lipat dibandingkan target MDGs. Pada tahun 2018, AKI mengalami penurunan sebanyak 205 kematian ibu per 100.000 kelahiran hidup di Indonesia. Berdasarkan laporan Ditjen Kesehatan Masyarakat, Kemenkes RI tahun 2020 menunjukkan bahwa, jumlah kematian ibu menurut provinsi tahun 2018-2019 terdapat penurunan dari 4.226 menjadi 4.221 kematian ibu di Indonesia. Jumlah kematian ibu di Jawa Barat tahun 2018 sebanyak 79,7 jiwa dari 100.000 jumlah lahir hidup dan pada tahun 2019 di Jawa Barat mengalami penurunan sebanyak 78,3 jiwa dari 100.000 jumlah lahir hidup (Kemenkes RI, 2019). Sedangkan di kabupaten sumedang belum mencapai 100.000 kelahiran sehingga indikator yang digunakan adalah Jumlah Kematian Ibu (Jiwa), tercatat sebanyak 16 jiwa kematian ibu dari seluruh kelahiran yang ada di kabupaten Sumedang (Bappeda Kabupaten Sumedang, 2018).

Pada tahun 2019 penyebab kematian ibu terbanyak adalah perdarahan (1.280 kasus), hipertensi dalam kehamilan (1.066 kasus), dan infeksi (207 kasus). Hal tersebut, yang menyebabkan AKI yang salah satunya dipengaruhi oleh faktor risiko yang terjadi pada ibu hamil (Kemenkes RI, 2019). Kehamilan risiko tinggi adalah kehamilan yang akan menyebabkan terjadinya bahaya dan komplikasi yang lebih besar baik pada ibu maupun pada janin dalam kandungan serta menyebabkan kematian, kesakitan, kecacatan, dan ketidak nyamanan. Pada ibu hamil yang memiliki risiko tinggi dibandingkan dengan kehamilan atau persalinan normal, maka akan memiliki bahaya yang lebih besar pada kehamilan/persalinannya (Widarta GD, Laksana MAC, Sulistyono A, 2015). Hasil dari penelitian Senewe, dkk menemukan bahwa, ibu hamil yang memiliki risiko tinggi 2,9 kali lebih berisiko untuk memiliki komplikasi persalinan. Kehamilan risiko tinggi ditemukan pada ibu hamil yang terlalu tua (diatas 35 tahun), terlalu muda (dibawah 20 tahun), terlalu banyak (lebih dari 4 kali), dan terlalu dekat (jarak melahirkan kurang dari 2 tahun) atau lebih dikenal dengan 4 Terlalu (4T) (P.Senewe \& Sulistiyowati, 2004).

Untuk menurunkan AKI maka dapat dilakukan dengan menjamin agar setiap ibu mampu mengakses pelayanan kesehatan ibu yang berkualitas, seperti pelayanan kesehatan ibu hamil, perawatan khusus dan rujukan jika terjadi komplikasi, dan deteksi dini risiko tinggi untuk mencegah 4T. Faktor risiko seperti usia dan paritas dapat menyebabkan banyak komplikasi bila tidak dilakukan skrining dan diatasi dengan baik. Pada usia ibu hamil tidak boleh terlalu muda ( $<20$ tahun) atau terlalu tua ( $>35$ tahun). 
Hal tersebut, dikarenakan jika terlalu muda secara fisik/anatomi belum siap karena rahim dan panggul belum tumbuh mencapai ukuran dewasa. Ibu yang hamil pertama pada usia $>35$ tahun mudah terjadi penyakit pada ibu, organ kandungan menua, dan jalan lahir menjadi kaku. Adapun bahaya yang dapat terjadi adalah hipertensi, preeklampsi, ketuban pecah dini, persalinan tidak lancar/macet, perdarahan setelah bayi lahir, dan bayi lahir dengan BBLR $<2500$ gram. Pada ibu hamil yang memiliki anak 4 akan lebih berisiko untuk mengalami komplikasi persalinan (Komariah \& Nugroho, 2020). Hal ini, dibuktikan dengan hasil penelitian Arisandi tahun 2016 bahwa, terdapat hubungan yang bermakna antara paritas dengan kejadian komplikasi persalinan (Arisandi et al., 2016).

Upaya BKKBN dalam menyukseskan program KB dengan memberikan edukasi kepada masyarakat mengenai 4T. Jikalau masyarakat sudah mengerti mengenai bahaya faktor risiko 4T, maka masyarakat akan lebih memperhatikan usia, sebelum merencanakan memiliki momongan agar tidak terlalu tua atau terlalu muda dan juga akan lebih memperhatikan jarak kehamilan (BKKBN, 2018). Namun, menurut penelitian Siti dkk (2019) yang dilakukan di desa Jahiang Kabupaten Tasikmalaya, pengetahuan ibu hamil mengenai faktor risiko 4T masih rendah yaitu 43,3\% (Nuraisyah, 2019). Menurut Notoatmojo (2003), pengetahuan individu akan memengaruhi perilaku individu tersebut. Maka dapat disimpulkan bahwa pengetahuan masyarakat terutama ibu hamil mengenai faktor risiko 4T masih belum baik (Mukhammad ABF, 2016). Berdasarkan pemaparan dan fenomena diatas, maka penelitian ini bertujuan untuk mengetahui gambaran kejadian risiko 4T pada ibu hamil di Puskesmas Jatinangor tahun 2020.

\section{METODE PENELITIAN}

Jenis penelitian yang digunakan adalah deskriptif dengan pendekatan cross sectional. Populasi dalam penelitian ini adalah seluruh ibu hamil yang memeriksakan diri ke Puskesmas Jatinangor periode bulan Januari-September 2020 yaitu berjumlah 2357 orang, dan didapatkan jumlah sampel sebanyak 149 orang. Pengambilan sampel dilakukan dengan teknik accidental sampling dimana pengambilan sampel berdasarkan data kohort ibu hamil dari Puskesmas Jatinangor pada periode bulan Januari-September 2020. Subjek penelitian ini, harus memenuhi kriteria inklusi dan eksklusi. Adapun kriteria inklusi pada penelitian ini adalah ibu hamil yang memiliki salah satu atau lebih dari risiko 4T, sedangkan kriteria eksklusi pada penelitian ini adalah ibu hamil yang tidak melakukan pemeriksaan kehamilan di PKM Jatinangor.

Variabel pada penelitian ini, adalah usia dengan kategori ibu $<20$ tahun dan $>35$ tahun dan paritas dengan kategori nullipara, primipara, multipara, dan grandemultipara. Sedangkan untuk kehamilan dengan risiko 4T, yaitu Terlalu Tua, Terlalu Muda, Terlalu Banyak dan Terlalu Dekat, akan tetapi pada data penelitian ini tidak ditemukan ibu dengan risiko terlalu dekat. Analisis data univariat disajikan dalam tabel distribusi frekuensi.

\section{HASIL PENELITIAN}

Dari hasil penelitian ini, mengenai gambaran risiko 4T pada ibu hamil di Puskesmas Jatinangor tahun 2020 yang dilakukan pada bulan september adalah sebagai berikut: 
Tabel 1. Distribusi Usia dan Paritas pada lbu Hamil yang Masuk Kriteria Risiko 4T di Puskesmas Jatinangor

\begin{tabular}{lcc}
\hline \multicolumn{1}{c}{ Kategori } & n (149) & $\%$ \\
\hline Usia & & \\
<20 Tahun & 55 & 36,8 \\
>35 Tahun & 94 & 63,2 \\
Paritas & & \\
Nullipara & 50 & 33,6 \\
Primipara & 27 & 18,1 \\
Multipara & 65 & 43,6 \\
Grandemultipara & 7 & 4,7
\end{tabular}

Sumber: Data Sekunder Kohort Puskesmas Jatinangor, 2020

Tabel 1. menunjukan bahwa responden yang memiliki risiko $4 \mathrm{~T}$ paling banyak pada usia lebih dari 35 tahun sebesar $63,19 \%$, dan pada paritas multipara sebesar $43,62 \%$.

Tabel 2. Distribusi Risiko 4T lbu Hamil berdasarkan Usia dan Paritas di Puskesmas Jatinangor Tahun 2020

\begin{tabular}{|c|c|c|c|c|c|c|}
\hline \multirow{3}{*}{ Karakteristik } & \multicolumn{6}{|c|}{ Risiko 4T } \\
\hline & \multicolumn{2}{|c|}{ Terlalu Tua } & \multicolumn{2}{|c|}{ Terlalu Muda } & \multicolumn{2}{|c|}{ Terlalu Banyak } \\
\hline & n (87) & $\%(58,4)$ & n (55) & $\%(36,9)$ & n (7) & $\%(4,7)$ \\
\hline \multicolumn{7}{|l|}{ Usia } \\
\hline$<20$ Tahun & N/A & $\mathrm{N} / \mathrm{A}$ & 55 & 36,9 & 0 & 0,0 \\
\hline >35 Tahun & 87 & 58,3 & $\mathrm{~N} / \mathrm{A}$ & $\mathrm{N} / \mathrm{A}$ & 7 & 4,7 \\
\hline \multicolumn{7}{|l|}{ Paritas } \\
\hline Nullipara & 1 & 0,7 & 49 & 32,9 & N/A & $N / A$ \\
\hline Primipara & 21 & 14,1 & 6 & 4,02 & N/A & $N / A$ \\
\hline Multipa & 58 & 38,9 & 0 & 0,0 & 0 & 0,0 \\
\hline Grandemultipara & 7 & 4,7 & 0 & 0,0 & 7 & 4,7 \\
\hline
\end{tabular}

Sumber: Data Sekunder Kohort Puskesmas Jatinangor, 2020

Tabel 2. menunjukkan bahwa, risiko $4 \mathrm{~T}$ yang paling banyak pada risiko terlalu tua sebesar $58,3 \%$ yang didominasi oleh multipara.

\section{PEMBAHASAN}

Berdasarkan hasil penelitian yang diambil dari data kohort ibu hamil periode bulan Januari-September 2020 ini, kasus ibu hamil dengan risiko 4T di Puskesmas Jatinangor dari total populasi sebanyak 2357 orang, terbanyak adalah kasus dengan risiko 4T kategori terlalu tua yaitu sebanyak 58,38 \%. Berdasarkan data Profil Kesehatan Indonesia tahun 2017 tentang kejadian kehamilan risiko tinggi, didapati bahwa salah satu faktor meningkatnya risiko $4 \mathrm{~T}$ adalah masih banyak ibu yang tidak menggunakan KB sehingga kehamilan di usia muda, di usia tua, dan pada ibu yang sudah memiliki banyak anak tidak dapat terhindarkan. Sebesar $36,78 \%$ ibu di indonesia tidak menggunakan KB, paling sedikit adalah daerah Papua. Untuk Jawa Barat sendiri, sebesar $33,35 \%$ ibu tidak menggunakan KB. banyak faktor yang mempengaruhi penggunaan KB di indonesia, salah satunya adalah pengetahuan ibu mengenai pentingnya $\mathrm{KB}$ dan bahaya dari risiko $4 \mathrm{~T}$. lbu dengan kehamilan risiko tinggi 
kemungkinan akan mengalami komplikasi yang lebih besar baik pada ibu maupun pada janin dalam kandungan dan dapat menyebabkan kematian, kesakitan, kecacatan, ketidaknyamanan dan ketidakpuasan dibanding dengan ibu yang tidak memiliki kehamilan risiko tinggi (Kemenkes RI, 2018).

Menurut teori Manuaba kategori terlalu muda adalah ibu yang berusia $<20$ tahun dan terlalu tua adalah ibu yang berusia $>35$ tahun (Manuaba, 2007). Dimana usia atau umur berdasarkan depkes RI (2009) adalah satuan waktu yang mengukur waktu keberadaan suatu benda atau makhluk, baik yang hidup maupun yang mati. Dalam hal ini, usia merupakan hasil hitung usia kini dengan tanggal lahir. Jika dilihat kriteria risiko 4T dari segi usia pada ibu hamil terdapat 149 responden dari jumlah kategori terlalu muda dan terlalu tua di Puskesmas Jatinangor, angka ini masih terbilang cukup banyak karena dari risiko 4T akan memicu terjadinya komplikasi dan kematian pada ibu.

Berdasarkan hasil penelitian ini pada tabel 1, didapatkan bahwa yang memiliki risiko $4 \mathrm{~T}$ paling banyak pada usia lebih dari 35 tahun sebesar $63,19 \%$. Usia ibu hamil lebih dari 35 tahun ini bisa terjadi karena ibu kurang memahami program KB dan umur reproduksi sehat. Pada ibu hamil dengan usia lebih dari 35 tahun bisa terjadi penurunan curah jantung yang dapan meningkatkan risiko komplikasi kehamilan seperti keguguran, eklamsia, dan perdarahan. Masalah lain pada tubuh ibu adalah terjadi perubahan dari jaringan alat-alat kandungan dan jalan lahir karena proses penuaan, menjadi lebih kaku dan ada kemungkinan besar bayi lahir cacat. Komplikasi yang dapat terjadi saat persalinan yaitu persalinan macet dan perdarahan pasca persalinan (Maria RA, 2011). Kehamilan ibu di atas 35 tahun akan memungkinkan terjadinya beberapa risiko tertentu, termasuk risiko kehamilan dimana hal tersebut disebabkan oleh semakin matangnya usia ibu. Menurut Rochjati, pada ibu umur >35 tahun akan mudah terjadi penyakit (anemia, malaria, tuberkulosa jantung, payah jantung, diabetes mellitus, HIV/AIDS, toksoplasmosis, dan pre-eklamsi ringan) dengan meningkatnya risiko abortus dan risiko kejadian kelainan kromosom, sehingga termasuk dalam kriteria risiko tinggi (Rochjati, 2004).

Sedangkan ibu hamil dengan risiko 4T terlalu muda menurut teori Manuaba, kehamilan dengan usia di bawah 20 tahun mempunyai risiko sering mengalami anemia, gangguan tumbuh kembang janin, keguguran, prematuritas, atau BBLR, gangguan persalinan, preeklampsia, dan perdarahan antepartum. Kehamilan $<20$ tahun dapat merugikan kesehatan ibu dan juga pertumbuhan perkembangan janin karena belum matangnya alat reproduksi untuk hamil. Keadaan tersebut akan semakin menyulitkan jika adanya tekanan (stress) psikologi, sosial, dan ekonomi pada ibu sehingga memudahkan terjadinya keguguran (Manuaba, 2007). Hal tersebut sejalan dengan penelitian yang dilakukan oleh Winkjosastro tahun 2010, bahwa wanita hamil dan melahirkan $<20$ tahun memiliki risiko 2-5 kali lebih tinggi terjadi kematian maternal dari pada wanita hamil dan melahirkan usia 20-29 tahun. Selain itu, kematian ibu akan meningkat kembali sesudah usia 30-35 tahun. Pada ibu hamil dengan usia $<20$ tahun berisiko 4 kali lipat mengalami penyulit atau komplikasi yang dapat meninggal akibat melahirkan (Winkjosastro, 2010). Penelitian ini hampir sama dengan penelitian Dien di Puskesmas Lubuk Gadang, dimana tingginya kehamilan risiko tinggi dikarenakan masih tingginya frekuensi faktor risiko pada ibu hamil dengan usia kehamilan risiko tinggi (<20 tahun dan >35 tahun) (Dien, 2015). Selain itu juga, ditunjang dengan hasil penelitian Felly yang menemukan terdapat hubungan antara umur dengan kehamilan risiko tinggi (P.Senewe \& Sulistiyowati, 2004). 
Paritas merupakan banyaknya kelahiran hidup yang dimiliki oleh seorang perempuan (BKKBN, 2006). Paritas terdiri dari, nullipara atau wanita yang belum pernah melahirkan, primipara atau wanita yang pernah melahirkan bayi hidup pertama kalinya, multipara atau wanita yang telah melahirkan 2-4 kali, dan grandemultipara atau wanita yang telah melahirkan 5 anak atau lebih (Manuaba, 2007). Berdasarkan hasil penelitian ini pada tabel 1 didapatkan bahwa risiko 4T paling banyak terdapat pada ibu hamil multipara. Hal tersebut sesuai dengan teori Wiknjosastro, bahwa ibu yang pernah melahirkan lebih dari satu kali atau paritas $\geq 4$ memiliki angka kematian maternal lebih tinggi. Sehingga semakin tinggi paritas, maka akan semakin tinggi kematian maternal. Salah satu cara untuk mengurangi atau mencegah risiko ini yaitu dengan menggunakan KB (Maria RA, 2011).

Pada penelitian Maryunani tahun 2016 menyatakan bahwa hingga pada paritas 3, rahim ibu bisa kembali seperti sebelum hamil. Tetapi untuk paritas ibu yang lebih dari 3 keelastisitasan otot-otot rahim tidak kembali seperti sebelum hamil diakibatkan mengalami peregangan pada saat kehamilan. Jarak kehamilan yang optimal dianjurkan adalah 36 bulan (Maryunani A, 2016). Hal ini ditunjang oleh penelitian Dien tahun 2015 yang menyatakan bahwa, dampak kehamilan risiko tinggi ibu hamil akibat paritas lebih dari 3 atau terlalu banyak jika tidak segera ditanggulangi, akan mengalami perdarahan, anak lahir dengan berat badan rendah dan tidak sedikit berakhir dengan persalinan operasi Caesar (Dien, 2015). Sejalan dengan hasil penelitian kaye pada tahun 2013 bahwa, Paritas 1 dan paritas tinggi (lebih dari 3) mempunyai angka kematian maternal yang lebih tinggi (Wellings, 2013). Maka dari itu salah satu faktor risiko tinggi pada kehamilan responden adalah terdapat kehamilan dengan paritas multipara, dimana fungsi uterus akan semakin menurun seiring dengan menuanya organ-organ pada ibu bersalin dalam hal ini disebabkan oleh faktor usia ibu. Jadi, dari segi usia ibu yang terlalu tua dengan paritas lebih dari 3 akan berpengaruh terhadap kejadian komplikasi yang terjadi pada ibu hamil. Sejalan dengan penelitian yang dilakukan oleh Dien yang mengatakan bahwa ada hubungan yang bermakna antara paritas dengan kehamilan risiko tinggi (Dien, 2015).

Hasil penelitian ini menunjukkan masih adanya ibu hamil yang termasuk ke dalam risiko 4T, dimana seperti yang telah diketahui dari risiko kehamilan akan memungkinkan untuk berakibat komplikasi dan kematian. Namun, diharapkan hal tersebut tidak akan menambah AKI di indonesia yang mana program pemerintah menargetkan penurunan AKI pada tahun 2020 sebesar 180 per 100.000 kelahiran hidup (Kemenkes RI, 2019). Ibu hamil dengan kehamilan risiko tinggi akan mempunyai risiko atau bahaya yang lebih besar pada kehamilannya atau persalinannya dibandingkan dengan kehamilan atau persalinan normal. Hal ini akan membuat jiwa dan keselamatan ibu serta bayinya dapat terancam, namun akan menjadi tidak berisiko jika terdeteksi dan ditangani sedini mungkin (Dien, 2015).

\section{SIMPULAN DAN SARAN}

Simpulan pada penelitian ini bahwa ibu hamil yang memiliki risiko 4T paling banyak pada usia lebih dari 35 tahun sebesar $63,19 \%$, dan pada paritas multipara sebesar $43,62 \%$ dimana didominasi oleh risiko terlalu tua. Disarankan untuk tenaga kesehatan terutama Bidan untuk berperan aktif dalam mendeteksi kehamilan risiko tinggi setiap kunjungan antenatal care. Dengan demikian, bidan harus memberikan konseling kepada ibu hamil tentang faktor risiko 4T untuk menghindari komplikasi 
dalam kehamilan yang akan menimbulkan kematian ibu, sehingga dapat membantu menurunkan AKI di Indonesia.

\section{DAFTAR PUSTAKA}

Arisandi, M. E., Anita, A., \& Abidin, Z. (2016). Faktor-Faktor yang Berhubungan dengan Kejadian Komplikasi Persalinan di Wilayah Kerja Puskesmas Tanjung Bintang Kabupaten Lampung Selatan. Jurnal Kesehatan, 7(2), 204. https://doi.org/10.26630/jk.v7i2.189

Bappeda Kabupaten Sumedang, B. K. S. (2018). Gambaran Umum Kondisi Daerah. Rencana Pembangunan Jangka Menengah Daerah (RPJMD) Kabupaten Sumedang. http://bappppeda.sumedangkab.go.id/file/BAB II GAMBARAN UMUM KONDISI DAERAH.pdf

BKKBN. (2018). Sosialisasi 4T. Http://Kampungkb.Bkkbn.Go.Id/PostSlider/4536/26070. http://kampungkb.bkkbn.go.id/

Dien, G. A. N. (2015). Kehamilan Risiko Tinggi Di Puskesmas Lubuk Gadang Kabupaten Solok Selatan. Jurnal Kesehatan Masyarakat Andalas, 9(1), 23-28.

Kemenkes RI. (2018). Profil Kesehatan Indonesia 2018 [Indonesia Health Profile 2018]. http://www.depkes.go.id/resources/download/pusdatin/profil-kesehatan-indonesia/Datadan-Informasi_Profil-Kesehatan-Indonesia-2018.pdf

Kemenkes RI. (2019). Profil Kesehatan Indonesia Tahun 2019. In Kementrian Kesehatan Repoblik Indonesia (Vol. 42, Issue 4).

Komariah, S., \& Nugroho, H. (2020). Hubungan Pengetahuan, Usia Dan Paritas Dengan Kejadian Komplikasi Kehamilan Pada Ibu Hamil Trimester lii Di Rumah Sakit lbu Dan Anak Aisyiyah Samarinda. KESMAS UWIGAMA: Jurnal Kesehatan Masyarakat, 5(2), 83. https://doi.org/10.24903/kujkm.v5i2.835

Kurniasari, D., JURNAL, F. A.-H., \& 2015, undefined. (2015). Hubungan Usia, Paritas Dan Diabetes Mellitus Pada Kehamilan Dengan Kejadian Preeklamsia Pada lbu Hamil Di Wilayah Kerja Puskesmas Rumbia Kabupaten. Ejurnalmalahayati.Ac.ld, 9(3), 142-150. http://ejurnalmalahayati.ac.id/index.php/holistik/article/view/232

Manuaba. (2007). Pengantar kuliah Obstetri. Buku Kedokteran EGC.

Maria RA. (2011). Gambaran faktor ibu hamil resiko tinggi tahun 2005-2010 (Di Polindes Sambikerep Kecamatan Rejoso Kabupaten Nganjuk). Jurnal Penelitian Kesehatan Suara Forikes, 2(1). http://fmipa.umri.ac.id/wp-content/uploads/2016/06/novelia-kumpulanjurnal.pdf\#page $=5$

Maryunani A. (2016). Buku Praktis Kehamilan dan Persalinan Patologis (Resiko Tinggi dan Komplikasi). TIM.

Mukhammad ABF. (2016). Hubungan Antara Pengetahuan dan Sikap dengan Perilaku Konsumsi Jajanan Sehat Di MI Sulaimaniyah Mojoagung Jombang. Airlangga University.

Nuraisyah, S. (2019). Gambaran Pengetahuan Ibu Hamil Tentang Risiko 4T Desa Jahiang Kecamatan Salawu Kabupaten Tasikmalaya. Jurnal Kesehatan Bakti Tunas Husada: Jurnal IImu-IImu Keperawatan, Analis Kesehatan Dan Farmasi, 19(2), 304. https://doi.org/10.36465/jkbth.v19i2.506

P.Senewe, F., \& Sulistiyowati, N. (2004). Faktor-Faktor Yang Berhubungan dengan komplikasi persalinan tiga tahun terakhir di Indonesia. In Puslitbang Ekologi Kesehatan (Vol. 32, Issue 2, pp. 83-91).

Rochjati, P. (2004). Skrining Antenatal Pada Ibu Hamil (F. K. U. Airlangga (ed.); 2nd ed.). Fakultas Kedokteran Universitas Airlangga, Airlangga University press.

Wellings, K. E. all. (2013). The prevalence of unplanned pregnancy and associated factors in Britain: findings from the third National Survey of Sexual Attitudes and Lifestyles (Natsal3). Journal Research Department of Infection and Population Health, University College London. https://www.ncbi.nlm.nih.gov/pmc/articles/PMC3898922/

Widarta GD, Laksana MAC, Sulistyono A, P. W. (2015). Deteksi Dini Risiko Ibu Hamil dengan Kartu Skor Poedji Rochjati dan Pencegahan Faktor Empat Terlambat. Majalah Obstetri \& 
Ginekologi, 1(23), 28-32. https://doi.org/http://dx.doi.org/10.20473/mog.V23I12015.2832

Winkjosastro, H. (2010). Ilmu Kebidanan. Yayasan Bina Pustaka Sarwono Prawirohardjo. 